\title{
Immuntoksin finner og dreper kreftceller
}

\section{Transgene alger kan lage immun- toksiner som har en målsøkende antistoffkomponent og en toksin- del som dreper målcellen.}

Neste generasjons kreftterapi kan bestå i toksiner som selv finner frem til og selektivt angriper kreftceller. Forskere har nå klart å

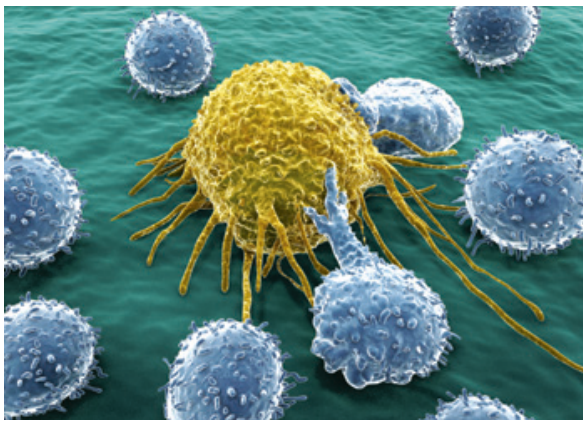

Illustrasjonsfoto Istockphoto tilføre grønnalgen Chlamydomonas reinhardtii et DNA-konstrukt som koder for både et antistoff rettet mot en overflatekomponent $i$ en kreftcelle og enzymdelen av et toksin (1). I studien har de brukt eksotoksin A fra Pseudomonas aeroginosa $o g$ overflatekomponenten CD22-antigen fra B-celler. Algen kan dyrkes opp i kolossale mengder, og produserer samtidig toksin. DNA-konstruktet tilføres kloroplasten $\mathrm{i}$ algecellen, og det prokaryotliknende proteinsynteseapparatet i kloroplasten angripes ikke av det aktuelle toksinet.

- Funnene er interessante og løser flere problemer når det gjelder målstyring av toksiner til kreftceller, sier professor Bjarne Bogen, Avdeling for immunologi og transfusjonsmedisin, Universitetet i Oslo og Oslo universitetssykehus. - Problemet med bruk av toksiner i behandling av kreft har vært uspesifikk toksisitet mot andre celler enn kreftcellene. Man har prøvd å målstyre toksinet mot kreftceller ved hjelp av antistoffer som spesifikt binder overflatemolekyler på kreftcellene. Kjemisk kobling av toksinet til anti- stoffer er ressurskrevende. Mer elegant er det å fusjonere genene for toksinet og antistoffet. Slike genkonstruksjoner kan transfekteres inn i eukaryote celler, men de transfekterte cellene vil dø på grunn av toksinpåvirkning. Forfatterne har løst dette problemet ved å benytte kloroplasten i grønnalger som produsenter av det målstyrte toksinet, uten at algecellene blir synderlig affisert. Det målstyrte toksinet kan så renses opp. Forfatterne viser at målstyrt toksin binder og dreper kreftceller både in vitro og in vivo i mus, så funnene er lovende. Det er imidlertid langt frem til applikasjon på pasienter.

\section{Haakon B. Benestad \\ h.b.benestad@medisin.uio.no \\ Universitetet i Oslo}

Litteratur

1. Tran M, Van C, Barrera DJ et al. Production of unique immunotoxin cancer therapeutics in algal chloroplasts. Proc Natl Acad Sci U S A 2013: 110: E15-22.

\section{Kommunikasjonskurs gir langtidseffekter}

\author{
To dagers kommunikasjonskurs førte til varig endring i praksis og økt \\ innsikt i egne kommunikasjonsferdigheter.
}

Det er kjent at det ikke er godt samsvar mellom tillit til egne ferdigheter (mestringstillit) og faktisk kvalitet. Dette gjelder også kommunikasjonsferdigheter. På dette området foreligger det imidlertid få studier med oppfølgingstid lengre enn tre måneder.

Vi gjennomførte i 2007-08 en krysset randomisert, kontrollert studie der en representativ gruppe sykehusleger gjennomgikk 20 timers kommunikasjonskurs. Deltakerne ble videofilmet i lege-pasient-møter før og etter kurset, åtte observasjoner hver. Kommunikasjonskvaliteten ble vurdert. Ved kursstart og straks etter kurset svarte legene på et skjema for beregning av mestringstillit med henblikk på kommunikasjon. Kurset førte til forbedret mestringstillit (1) og til økt kommunikasjonskvalitet (2).

Vi ønsket å finne ut hvordan kurset og erfaringene kunne ha påvirket mestringstilliten tre år senere, og deltakerne fikk derfor svare på det samme skjemaet i 2011. Siden vi hadde observert at det ikke var noe samsvar mellom mestringstillit og kommunikasjonskvalitet før kurset, var vi også interessert $\mathrm{i}$ om kurset kunne ha ført til en endring på dette punktet. Vi fant at mest- ringstilliten ikke hadde falt signifikant i oppfølgingstiden. Derimot så vi at det i 2011 var samsvar mellom mestringstilliten og kommunikasjonskvalitet etter kurset. $59 \%$ av deltakerne svarte at kurset hadde ført til varig endring av deres praksis (3).

Vi mener at kurset førte til en realitetsorientering, og at de som nyttiggjorde seg kurset og gjorde positive erfaringer som følge av det, fikk økt mestringstillit.

\section{Pål Gulbrandsen}

pal.gulbrandsen@medisin.uio.no

Universitetet i Oslo

og

Akershus universitetssykehus

\section{Litteratur}

1. Gulbrandsen P, Jensen BF, Finset A. Endring i mestringstillit hos sykehusleger etter kurs i klinisk kommunikasjon. Tidsskr Nor Legeforen 2009, 129: 2343-6.

2. Jensen BF, Gulbrandsen P, Dahl FA et al. Effectiveness of a short course in clinical communication skills for hospital physicians: results of a crossover randomized controlled trial. Patient Educ Couns 2011; 84: 163-9.

3. Gulbrandsen P, Jensen BF, Finset A et al. Longterm effect of communication training on the relationship between physicians' self-efficacy and performance. Patient Educ Couns 2013; e-publisert 12.2.2013.

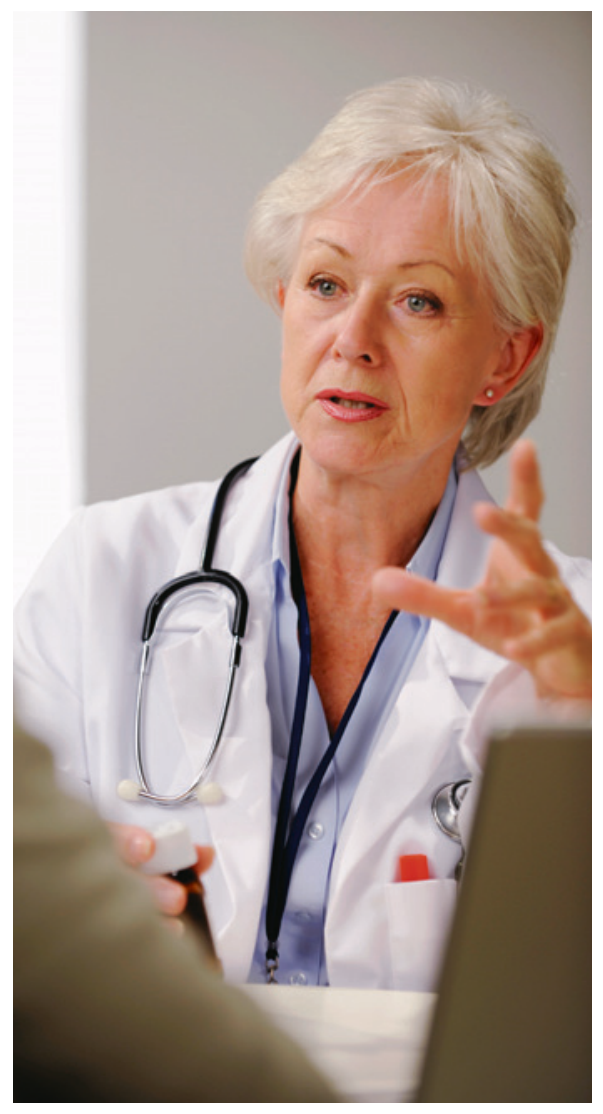

Illustrasjonsfoto Istockphoto 